\title{
MAKSIM KUANTITAS DAN MAKSIM KUALITAS DALAM TUTURAN BAHASA INDONESIA PADA ANAK DISABILITAS INTELEKTUAL
}

Quantity Maxim and Quality Maxim in Indonesian Speech of Children with Intellectual Disabilities

\author{
Ira Eko Retnosari dan Rahayu Pujiastuti \\ Universitas PGRI Adi Buana Surabaya \\ Jalan Dukuh Menanggal XII, Kec. Gayungan, Kota Surabaya, Jawa Timur, Indonesia \\ ira@unipasby.ac.id
}

Naskah Diterima Tanggal 26 Februari 2021—Direvisi Akhir Tanggal 21 Juli 2021—Disetujui Tanggal 1 Desember 2021 doi: https://doi.org/10.26499/rnh/v9i2.4053

\begin{abstract}
Abstrak
Tujuan penelitian ini adalah mendeskripsikan penguasaan maksim kuantitas dan maksim kualitas dalam tuturan bahasa Indonesia pada anak disabilitas intelektual. Dalam penelitian ini, digunakan metode penelitian deskriptif kualitatif. Sumber data penelitian ini adalah satu anak disabilitas intelektual berusia 9;0. Data penelitian ini adalah kata, frasa, dan kalimat yang mengandung maksim kuantitas dan maksim kualitas. Pengumpulan data yang digunakan dalam penelitian ini meliputi observasi, pemancingan, perekaman, dan catatan lapangan. Adapun tahap-tahap pengumpulan data adalah melakukan observasi, merekam tuturan, mentranskrip tuturan, dan memvalidasi data. Dalam penganalisisan data, digunakan metode padan pragmatik. Prosedur penganalisisan data meliputi mereduksi data, menginterpretasi data, dan menyimpulkan. Hasil analisis data menunjukkan bahwa anak disabilitas mental sudah mampu menguasai maksim kuantitas dan maksim kualitas. L sudah mampu menggunakan maksim kuantitas dengan bertutur tidak berlebihan dan maksim kualitas dengan bertutur sesuai kenyataan. Maksim kuantitas dan maksim kualitas yang ditunjukkan L masih didominasi dengan satu kata meskipun tuturan L terlihat sudah mampu menggunakan multikata. Akan tetapi, maksim kuantitas dan maksim kualitas yang digunakan $\mathrm{L}$ masih mengalami kekurangsempurnaan pelafalan bunyi seperti [r] dilafalkan menjadi [1], dan bunyi [s] yang terletak pada awal dan tengah kata diganti dengan [t]. Selain itu, L masih belum mampu menggunakan afiks sehingga mengalami defisit afiks.
\end{abstract}

Kata-kata Kunci: maksim kuantitas, maksim kualitas, tuturan, anak disabilitas intelektual

\begin{abstract}
The purpose of this study was to describe the mastery of maxims of quantity and maxims of quality in Indonesian speech in children with intellectual disabilities. In this study, a qualitative descriptive research method was used. The data source of this research is one child with intellectual disability aged 9;0. The data of this research are words, phrases, and sentences that contain maxims of quantity and maxims of quality. The data collection used in this study includes observation, fishing, recording, and field notes. The stages of data collection are making observations, recording speeches, transcribing speeches, and validating data. In analyzing the data, the pragmatic equivalent method was used. Data analysis procedures include reducing data, interpreting data, and concluding. Based on data analysis, it can be concluded that children with intellectual disabilities have been able to master the maxim of quantity and maxim of quality. $L$ 's speech is able to show its contribution to the speech partner to show the maxim of strength by speaking not excessively and maxim of quality by speaking according to reality. The maxim of quantity and maxim of quality shown by L are still dominated by one word even though $L$ 's speech seems to be able to use multi-words. However, the maxim of quantity and maxim of quality used by L still suffer from imperfect pronunciation of sounds such as [r] is pronounced as [l], and the
\end{abstract}


sound [s] which is located at the beginning and middle of the word is replaced with [t]. In addition, $L$ is still unable to use affixes so that he experiences an affix deficit.

Keywords: maxim of quantity and maxim of quality, Indonesian speech, children with intellectual disabilities

How to Cite: Retnosari, Ira Eko dan Rahayu Pujiastuti. (2021). Maksim Kuantitas dan Maksim Kualitas dalam Tuturan Bahasa Indonesia pada Anak Disabilitas Intelektual. Ranah: Jurnal Kajian Bahasa, 10(2). 270-282. doi: https://doi.org/10.26499/rnh/v9i2.4053

\section{PENDAHULUAN}

Salah satu fenomena perkembangan anak yaitu anak lahir secara tidak normal. Hal tersebut menyebabkan perkembangan anak terhambat. Hambatan perkembangan anak seperti anak terindikasi memiliki gejala keterlambatan. Keterlambatan tersebut memerlukan tindakan yang berbeda dari anak lainnya. Anak yang mengalami keterlambatan disebut anak disabilitas intelektual. Anak disabilitas intelektual adalah anak yang memiliki gangguan fungsi kognitif secara global dan defisit signifikan dalam fungsi adaptif, bermanifestasi sebelum usia 18;0 (Schalock et al., 2010). Disabilitas intelektual menggambarkan tentang kemampuan yang dijalankan oleh individu. Individu tersebut biasanya memengaruhi kehidupan penyandangnya, baik dalam berinteraksi maupun berkontribusi di masyarakat sesuai dengan persamaan hak.

Pada umumnya, anak tersebut mengalami keterlambatan perkembangan. Anak tersebut memiliki hambatan pada satu zona atau lebih seperti bina diri, kemandirian, komunikasi dan keterampilan sosial yang digunakan untuk masuk dalam suatu komunitas. Selain itu, anak disabilitas intelektual sering memiliki risiko kesulitan dalam bermasyarakat dan perkembangan emosional. Anak disabilitas intelektual memiliki perbedaan dengan anak normal lainnya. McLaughlin (2011) menjelaskan anak atau remaja yang memiliki disabilitas intelektual mengalami kesulitan berbicara. Kesulitan berbicara yang dimaksud memiliki keterkaitan dengan bahasa dan tuturan. Tiel (2016) berpendapat terdapat dua kesulitan berbicara atau gangguan berbicara pada anak. Pertama, gangguan bicara ekspresif, yaitu kesulitan seseorang mengemukakan sesuatu melalui bahasa yang sesuai dengan kemampuan rata-rata orang seusianya. Misalnya, gangguan aksen, penggunaan intonasi, penekanan, artikulasi, dan sebagainya. Kedua, gangguan bicara reseptif, yaitu kondisi seseorang sulit menerima atau memahami sebuah informasi bahasa baik bahasa verbal maupun nonverbal. Bahasa dan tuturan pada anak disabilitas intelektual menunjukkan kesulitan dalam mengomunikasikan dan merangkai kata dengan baik sehingga informasi yang disampaikan kurang jelas.

Perkembangan anak disabilitas intelektual berbeda dengan anak normal, misalnya pada tuturan. Beberapa anak tersebut mengalami kesulitan dalam merangkai kata-kata atau perkembangan bahasanya terlambat. Hal itu dapat dilihat dari tuturan yang dihasilkan. Ada anak disabilitas intelektual sulit dalam menuturkan kata dengan sempurna. Pelafalan kurang sempurna ditunjukkan L yaitu pada maksim kuantitas seperti kata nambah-nambahan seharusnya dilafalkan penjumlahan. Selain itu, tuturan L juga masih terlihat menunjukkan kekurangsempurnaa pelafalan bunyi seperti bunyi [n] dan [t] masih sering dilafalkan tidak pada tempatnya seperti pada kata nambah seharuhnya tambah.

Tuturan anak disabilitas intelektual di atas membuktikan bahwa tuturannya masih menunjukkan kekurangsempurnaan dalam pelafalan. Kasih (2019) berpendapat bahwa disabilitas intelektual merupakan istilah baru dari retardasi mental. Disabilitas intelektual atau retardasi mental merupakan salah satu penyebab anak mengalami keterlambatan bicara. Retardasi mental merupakan penurunan fungsi intelektual yang menyeluruh secara bermakna dan secara langsung menyebabkan gangguan adaptasi sosial dan bermanifestasi selama masa perkembangan (Sularyo \& Kadim, 2016). 
Disabilitas intelektual memiliki karakteristik utama. Pertama, perkembangan kognitif (berpikir) anak yang buruk. Biasanya, anak memperoleh skor kurang dari 70 pada tes inteligensi. Kedua, anak mengalami penurunan fungsi adaptif. Fungsi adaptif merujuk pada kemampuan anak memiliki sikap mandiri. Ketiga, gangguan disabilitas intelektual dialami sebelum usia 18;0 (Kasih, 2019). Anak disabilitas intelektual akan berisiko dalam perkembangannya. Misalnya, kemampuan konseptual dan prestasi pendidikan, faktor personal, dan sosial. Menurut Somantri (2007), anak retardasi mental memiliki keterbelakangan mental yang menunjukkan fungsi intelektual dibawah rata-rata secara jelas dengan disertai ketidakmampuan dalam menyesuaikan diri dengan lingkungan dan terjadi pada masa perkembangan. Pada umumnya, anak disabilitas intelektual mengalami keterlambatan bicara. Oleh sebab itu, subjek penelitian ini dipilih anak disabilitas intelektual yang mengalami keterlambatan bicara.

Anak berketerlambatan berbicara memiliki tuturan yang unik. Hal tersebut yang melatarbelakangi pemilihan tuturan anak disabilitas intelektual yang mengkaji maksim kuantitas dan maksim kualitas. Djajasudarma (2012) menyatakan bahwa syarat maksim kuantitas adalah menuntut penutur harus berbicara seperlunya dan berbicara sebatas apa yang diperlukan, jangan bertele-tele, ada kontribusi informasi sebatas yang diperlukan, jangan memberikan sumbangan informasi yang lebih dari yang diberikan.

Grice (1975) menjelaskan bahwa maksim kualitas berkarakteristik utama penutur memberikan informasi yang tepat dan benar kepada mitra tutur. Lebih lanjut, Rohmadi (2011) mengatakan maksim kualitas mewajibkan setiap peserta percakapan setidak-tidaknya didasarkan pada bukti-bukti yang memadai. Dengan demikian, maksim kualitas menuntut penutur harus melakukan (1) jangan berbicara apabila kenyataan tidak yakin benar dan (2) data yang diungkapkan harus lengkap dan akurat.

Berdasarkan penjelasan-penjelasan di atas, penelitian ini menarik untuk dikaji. Fokus penelitian ini adalah bagaimana penguasaan maksim kuantitas dan maksim kualitas dalam tuturan bahasa Indonesia pada anak disabilitas intelektual. Penelitian ini diharapkan dapat memberikan manfaat bagi pembaca atau peneliti untuk mengetahui kemampuan menggunakan maksim kuantitas dan maksim kualitas pada anak disabilitas intelektual sehingga dapat dijadikan acuan saat berinteraksi dengan anak tersebut.

\section{LANDASAN TEORI}

Disabilitas intelektual atau yang sering dikenal dengan retardasi mental atau tunagrahita adalah disabilitas yang dicirikan dengan adanya keterbatasan signifikan, baik dalam fungsi intelektual (kapasitas mental umum, seperti belajar, bernalar, berpakaian, makan, berkomunikasi, mencari solusi) maupun tingkah laku adaptif yang meliputi banyak keterampilan sosial dan praktis sehari-hari. Mustikawati et al. (2015) mengatakan anak disabilitas intelektual sering mengalami perkembangan mental yang terhenti atau tidak lengkap. Kondisi seperti itu ditandai adanya hambatan keterampilan selama masa perkembangan dan mengakibatkan kesulitan saat bersosialisasi dengan orang lain, misalnya berkomunikasi, bekerja, bersantai, dan menjalin komunikasi dengan mitra tutur.

Salah satu penyebab anak disabilitas intelektual adalah anak yang memiliki IQ di bawah anak normal. Efendi (2006) mengatakan disabilitas intelektual terdiri atas tiga kategori dilihat berdasarkan tingkat IQ (intelligence quotient) dari penyandang, yakni disabilitas intelektual ringan (mampu didik) dengan IQ yang berkisar antara 50-75, disabilitas intelektual sedang (mampu latih) dengan IQ yang berkisar antara 25-50, dan disabilitas intelektual berat (mampu rawat) dengan IQ yang berkisar antara 0-25.

Subjek penelitian ini selain disabilitas intelektual juga terlambat bicara. Shetty (2012) mengatakan penyebab yang memengaruhi terlambat bicara adalah retardasi mental, gangguan 
pendengaran, keterlambatan maturasi, gangguan bahasa ekspresif, bilingualisme, perampasan psikososial, autisme, mutisme selektif, afasia reseptif, dan cerebral palsy. Pendapat tersebut relevan dengan penelitian ini yaitu subjek penelitian mengalami keterlambatan bicara karena retardasi mental. Leung \& Kao (1999) mengatakan bahwa retardasi mental adalah penyebab paling umum keterlambatan bicara, terhitung lebih dari 50 persen kasus.

Dalam penelitian ini, dikaji prinsip kerja sama. Rahardi (2005) mengatakan bahwa setidak-tidaknya prinsip kerja sama harus dilakukan oleh penutur dan mitra tutur agar proses komunikasi dapat berjalan dengan baik. Menurut Grice (1975), prinsip kerja sama terdiri atas maksim kuantitas (maxim of quantity), maksim kualitas (maxim of quality), maksim relevansi (maxim of relevance), dan maksim cara (maxim of manner). Berikut ini dipaparkan keempat maksim tersebut.

Pertama, maksim kuantitas berkaitan dengan kontribusi tuturan yang diberikan penutur. Artinya, maksim kuantitas mengharapkan tuturan yang diberikan sesuai dengan keperluan mitra tutur. Leech (1993) mengatakan maksim kuantitas menghendaki setiap peserta tutur hanya memberikan kontribusi yang secukupnya atau sebanyak yang diperlukan mitra tutur. Kedua, maksim kualitas mewajibkan setiap peserta percakapan hendaknya didasarkan pada bukti-bukti yang memadai. Menurut Abdul (2006), maksim kualitas harus menunjukkan bukti untuk meyakinkan kebenaran dari peristiwa tutur yang terjadi. Ketiga, maksim relevansi mewajibkan setiap peserta percakapan memberikan kontribusi yang sesuai dengan masalah pembicaraan (Wijana \& Rohmadi, 2010). Sejalan dengan mereka, Rahardi (2009) menekankan bahwa maksim relevansi menuntut penutur memberikan kontribusi yang baik kepada mitra tutur dengan topik yang sesuai sehingga terjalin kerja sama yang baik. Keempat, maksim cara mewajibkan penutur melakukan komunikasi dengan mitra tutur dengan secara langsung, tidak kabur, dan jelas.

Pada penelitian ini, dikaji maksim kuantitas dan maksim kualitas. Untuk mengkaji maksim kuantitas dan maksim kualitas anak disabilitas intelektual, digunakan teori psikolinguistik dan pragmatik. Pada dasarnya, anak disabilitas intelektual termasuk dalam anak berkebutuhan khusus (ABK). ABK memiliki keterbatasan dalam perkembangan bahasa. Oleh sebab itu, digunakan kajian psikolinguistik dan pragmatik untuk menelaah penggunaan maksim anak disabilitas intelektual.

Subjek penelitian (S) ini adalah anak disabilitas intelektual yang mengalami keterlambatan bicara. Artikel tentang anak terlambat bicara pernah ditulis oleh Nilawati \& Suryana (2012). Mereka menemukan anak yang memiliki gangguan keterlambatan bicara akan mengalami kesulitan ketika berinteraksi dengan orang lain dan dalam upaya mengembangkan keterampilan sosial akan menghadapi banyak kendala terutama yang terkait dengan komunikasi.

Penelitian yang terkait dengan anak disabilitas intelektual pernah diteliti oleh Pandudinata et al., (2018). Tujuan penelitian tersebut yaitu memaparkan kosakata dasar anak tunagrahita ringan dan berat siswa SLB kelas VI usia 9;0. Data yang digunakan yakni kosakata dasar. Hasil temuan penelitian menjelaskan bahwa anak tunagrahita ringan dapat menggunakan kosakata dasar sebanyak 170 kata dari 200 kata. Berbeda dengan anak tunagrahita berat, kosakata dasar yang dikuasai sebanyak 56 kata dari 200 kata.

Kedua penelitian di atas terdapat persamaan dan perbedaan dengan penelitian ini. $\mathrm{S}$ penelitian ini adalah anak disabilitas intelektual ringan berusia 9;0. Pada anak normal, anak sudah mampu memproses, memahami, dan menggunakan bahasa dengan baik untuk mencapai berbagai tujuan komunikatif. Menurut (Steinberg et al., 2001) anak memperoleh bahasa pertama secara sempurna sekitar usia 5;0. Berbeda dengan anak disabilitas ringan, pemerolehan bahasa pertama secara sempurna belum dapat ditentukan pada usia berapa. 


\section{METODE PENELITIAN}

Penelitian ini bertujuan mendeskripsikan penguasaan maksim kuantitas dan maksim kualitas pada anak disabilitas intelektual. Metode penelitian ini adalah deskriptif kualitatif. S ini yaitu anak disabilitas intelektual ringan berusia 9;0. Anak disabilitas intelektual ringan yang dijadikan $\mathrm{S}$ berusia 9;0 karena usia 9,0 dan 12;0 kematangan belajarnya baru dapat dicapai sesuai dengan kondisi berat dan ringannya kelainan (Wardani et al., 2008). Hal tersebut yang melatarbelakangi dipilih anak disabilitas intelektual ringan karena diharapkan dapat memperoleh data sebanyak-banyaknya.

Data penelitian ini berupa tuturan berbentuk kata, frasa, dan kalimat yang mengandung maksim kuantitas dan maksim kualitas. Tuturan tersebut diambil ketika berinteraksi dengan peneliti dan terapis.

S penelitian ini adalah anak disabilitas intelektual ringan yang mengalami keterlambatan bicara. Papalia et al. (2003) menjelaskan lebih detail tentang perkembangan anak terlambat bicara berdasarkan usia. Pertama, anak berketerlambatan bicara usia 2;0 memiliki kecenderungan salah dalam menyebutkan kata. Kedua, usia 3;0 memunyai perbendaharaan kata yang buruk. Ketiga, usia 5;0 memiliki kesulitan dalam menamai objek.

Dalam penelitian ini, pengumpulan data meliputi observasi, pemancingan, perekaman, dan catatan lapangan. Adapun tahap-tahap pengumpulan data adalah melakukan observasi, merekam tuturan, mentranskrip tuturan, dan memvalidasi data. Prosedur penganalisisan data dalam penelitian ini meliputi mereduksi data, menginterpretasi data, dan menyimpulkan. Dalam penganalisisan data, digunakan metode padan. Metode padan yaitu metode yang alat penentunya berasal dari luar bahasa yang bersangkutan. Untuk menganalisis tuturan digunakan padan pragmatik. Padan pragmatik mengidentifikasi satuan kebahasaan yang timbul ketika penutur bertutur dengan mitra tutur. Reaksi yang timbul saat bertutur diidentifikasi berdasarkan kontekstual.

Hasil dan temuan penelitian yang diperoleh dari tuturan L diabsahkan dengan cara melakukan pemeriksaan teori dan sumber. Triangulasi teori dilakukan peneliti dengan cara memahami kembali teori-teori yang memiliki keterkaitan dengan hasil dan temuan penelitian. Hasil pemeriksaan teori tersebut diperkuat peneliti dengan melakukan triangulasi sumber. Triangulasi sumber penelitian ini dilakukan pada anak disabilitas intelektual yang menjadi sumber data triangulasi dan pihak-pihak lain yang dipandang dapat memahami hasil dan temuan penelitian dengan analisis secara kritis. Setelah mendapatkan hasil dan temuan, peneliti menginformasikan hal tersebut dengan melakukan pengecekan pada sumber data triangulasi.

Peneliti mengonfirmasi kepada pihak yang terlibat seperti peneliti dan guru. Hasil konfirmasi tersebut menunjukkan L masih belum sempurna dalam melafalkan bunyi [r] dan [s] pada awal dan tengah kata. Bahkan, sampai penelitian ini selesai, L masih belum mampu melafalkan kedua bunyi tersebut dengan sempurna. Selain itu, L masih belum mampu melafalkan prefiks sehingga ia menunjukkan defisit awalan seperti $d i-$, ber-, me-.

Hasil pemeriksaan pada para sumber data triangulasi, peneliti dan guru tersebut, peneliti perkuat dengan melakukan pemeriksaan hasil dan temuan pada pihak-pihak terkait yang memiliki pemahaman terhadap penelitian ini. Peneliti berdiskusi dengan sesama peneliti tentang kebahasaan pada anak disabilitas intelektual. Hasil diskusi tersebut yaitu L sering menunjukkan defisit kata sehingga tuturan yang disampaikan tidak menunjukkan pola kalimat yang benar. Kemudian, jumlah tuturan L rerata satu kata, meskipun L sudah mampu menunjukkan multikata. Multikata yang ditunjukkan dua sampai tiga kata.

\section{PEMBAHASAN}

Analisis penelitian ini berupa deskripsi penguasaan maksim kuantitas dan maksim kualitas pada anak disabilitas intelektual. Berikut ini dipaparkan analisis data. 


\section{Penguasaan Maksim Kuantitas}

Dalam bahasa Indonesia, maksim kuantitas merupakan kaidah untuk tidak berbicara berlebihan, berte-tele, dan memberikan informasi sesuai dengan keperluan. Maksim kuantitas menghendaki setiap peserta tutur hanya memberikan kontribusi yang secukupnya atau sebanyak yang dibutuhkan mitra tutur. Oleh sebab itu, kontribusi tuturan yang diberikan tidak lebih atau kurang dari yang diperlukan petutur. Pada penelitian ini, maksim kuantitas diperoleh anak disabilitas intelektual pada tahap porsi atau kapasitas anak menjawab pertanyaan dari mitra tutur. Penguasaan maksim kuantitas anak disabilitas intelektual pada tahap porsi atau kapasitas anak memberikan kontribusi kepada mitra tutur dijelaskan sebagai berikut.

\begin{tabular}{|c|c|c|c|c|}
\hline \multicolumn{5}{|c|}{$\begin{array}{l}\text { Konteks } \\
\text { Di tempat terapi, L sedang duduk di depan TW yang sedang menyiapkan pelaratan terapi. Sebelum melakukan } \\
\text { terapi, TW bertanya kepada L kegiatan selama di sekolah. }\end{array}$} \\
\hline & & Data & & Interpretasi/Padanan \\
\hline TW: & (a) & $\begin{array}{l}\text { Main apa? (Menunjukkan kartu } \\
\text { bergambar) }\end{array}$ & TW: & $\begin{array}{l}\text { Bermain apa? (Menunjukkan kartu } \\
\text { bergambar) }\end{array}$ \\
\hline L: & (b) & Main bola. & L: & Bermain bola. \\
\hline TW: & (c) & $\begin{array}{l}\text { Main? Main apa? Main bola ? Oh } \\
\text { main bola. Bolanya besar apa kecil? } \\
\text { (Melihat L duduk dengan kaki } \\
\text { diangkat) Duduknya yang bagus! } \\
\text { Bolanya besar apa kecil? }\end{array}$ & TW: & $\begin{array}{l}\text { Main? Main apa? Main bola? Oh main bola. } \\
\text { Bolanya besar apa kecil? (Melihat L duduk } \\
\text { dengan kaki diangkat) Duduknya yang bagus! } \\
\text { Bolanya besar apa kecil? }\end{array}$ \\
\hline $\mathrm{L}:$ & (d) & Betal. & L: & Besar. \\
\hline
\end{tabular}

Pertuturan di atas terjadi saat TW menyiapkan media untuk menerapi L. Sambil TW menyiapkan media alat terapi, TW bertanya kepada L seperti pada tuturan (a). L menjawab pertanyaan TW seperti pada tuturan (b). TW menerima jawaban L dan bertanya kembali kepada L seperti pada tuturan (c). L menjawab pertanyaan TW seperti pada tuturan (d).

Data (1) menunjukkan tuturan L terdapat maksim kuantitas. Maksim kuantitas ditunjukkan L pada (b) dan (d) yaitu main bola dan betal (besar). Jawaban yang diberikan L sesuai dengan gambar yang ditunjukkan TW sehingga L memberikan kontribusi yang sesuai diharapkan TW. Meskipun tuturan L menunjukkan maksim kuantitas, L pada (b) menunjukkan kekurangsempurnaan pelafalan kata. L masih belum mampu melafalkan afiks. Kata main seharusnya dituturkan bermain. Kata bermain menunjukkan bahwa kartu bergambar mengandung aktivitas sedang bermain bola. Dengan demikian, L masih belum mampu menggunakan prefiks (ber-). L pada (d) juga terdapat kekurangsempurnaan pelafalan bunyi yaitu kata betal. L belum mampu melafalkan bunyi [s] pada tengah kata dan bunyi [r]. Oleh sebab itu, kata besar dilafalkan betal. L pada (d) juga mengandung maksim kuantitas. Penguasaan maksim kuantitas juga terlihat pada data (2) seperti berikut ini.

Data 2

Konteks

Di tempat terapi, L sedang duduk di depan TW yang sedang menyiapkan peralatan terapi. Sebelum melakukan terapi, TW bertanya kepada L terkait menu makan siang.

\begin{tabular}{lllll}
\hline \multicolumn{2}{c}{ Data } & \multicolumn{1}{c}{ Interpretasi/Padanan } \\
\hline TW: & (f) & Makan apa? & TW: & Makan apa? \\
L: & (g) & belum. & L: & belum. \\
TW: & (h) & $\begin{array}{l}\text { Sudah apa belum? Belum? Sudah } \\
\text { apa belum? }\end{array}$ & TW: & $\begin{array}{l}\text { Sudah makan apa belum? Belum? Sudah apa } \\
\text { L: }\end{array}$ \\
& (i) & Sudah. & L: & Selum? \\
TW: & (j) & Makan apa? & TW: & Makan apa? \\
L: & (k) & Ayam. & L: & Ayam. \\
TW: & (l) & Ayam. & TW: & Ayam. \\
\hline
\end{tabular}

Pertuturan di atas berawal saat TW bertanya kepada L di tempat terapi. Dalam pertuturan tersebut, TW sedang menyiapkan puzzle untuk melakukan terapi kepada L. Sebelum melakukan terapi, TW bertanya kepada L seperti pada tuturan (a). Akan tetapi, tuturan L tidak responsif 
sehingga ia menjawab pertanyaan TW seperti pada tuturan (b). TW merasa tidak yakin dengan tuturan L sehingga TW bertanya lagi kepada L seperti pada (c). L menjawab pertanyaan TW seperti pada tuturan (d). Setelah TW yakin dengan jawaban L, ia melanjutkan bertanya kepada L seperti pada tuturan (e). Kemudian, L menjawab pertanyaan TW seperti pada tuturan (f). L menjawab ayam karena makanan tersebut adalah makanan kesukaannya. TW menerima jawaban L seperti pada (g) dengan mengulang kembali jawaban L.

Data (2) menunjukkan tuturan L mengandung maksim kuantitas. Maksim kuantitas di atas ditunjukkan L pada (f) yaitu Ayam. L menjawab ayam karena lauk tersebut adalah kesukaannya. Kata ayam yang dituturkan L memberikan informasi yang cukup menurut TW. Informasi yang tidak berlebihan akan meminimalisasi terjadinya pelanggaran kerja sama sehingga L dan TW menunjukkan kerja sama yang baik dalam komunikasi. Dengan demikian, jawaban L pada (f) menunjukkan maksim kuantitas. Penguasaan maksim kuantitas juga terlihat pada data (3) seperti berikut ini.

\begin{tabular}{lllll}
\multicolumn{7}{l}{ Data 3} \\
\hline \multicolumn{7}{l}{ Konteks } \\
$\begin{array}{l}\text { Di tempat terapi, L dan S bersama-sama melakukan terapi dengan TW. L dan S sedang duduk bersila } \\
\text { menghadap TW. Kemudian, TW mengajukan beberapa pertanyaan kepada V. }\end{array}$ \\
\hline \multicolumn{5}{c}{ Data } \\
\hline TW: & (a) & Habis potong rambut? & \multicolumn{2}{c}{ Interpretasi/Padanan } \\
L: & (b) & (Menundukkan kepala) & TW: & L habis potong rambut? \\
TW: & (c) & Iya, L. & L: & (Menundukkan kepala) \\
L: & (d) & He em. & TW: & Iya, L. \\
\hline
\end{tabular}

Pertuturan di atas terjadi ketika TW melihat model rambut L yang berbeda dari biasanya. Saat itu, L duduk di depan TW karena akan terapi. Sebelum melakukan terapi, TW bertanya kepada L seperti pada tuturan (a). Respons yang diberikan L berupa gerakan tubuh seperti pada (b). Tuturan TW pada (c) terlihat tidak puas dengan jawaban L karena hanya menggunakan gerakan tubuh sehingga ia mempertegas maksud pernyataan L. Kemudian, L memberikan informasi kepada TW seperti pada tuturan (d).

Data (3) menunjukkan tuturan $\mathrm{L}$ terdapat maksim kuantitas. Maksim kuantitas ditunjukkan pada tuturan (b) dan (d). Tindakan L pada (b) yaitu menundukkan kepala hanya menunjukkan bahasa nonverbal ketika menjawab pertanyaan TW. Hal tersebut dikarenakan L masih malu-malu dalam menjawab sehingga ia menggunakan bahasa nonverbal. Meskipun L hanya mengungkapkan bahasa nonverbal, tuturan tersebut menunjukkan maksim kuantitas. Maksim kuantitas tidak terbatas hanya pada bahasa verbal. Maksim kuantitas dapat terjadi pada bahasa nonverbal dengan syarat bahwa penutur memberikan jawaban sesuai dengan yang diinginkan mitra tutur. Data (2) tersebut menunjukkan mitra tutur pada (c) memahami bahasa nonverbal yang ditunjukkan L sehingga L pada (b) menunjukkan maksim kuantitas. Kemudian, L pada (d) yaitu he em menjawab pertanyaan sesuai yang dikehendaki TW sehingga menunjukkan maksim kuantitas. Kata he em apabila diterjemahkan ke dalam bahasa Indonesia memiliki arti yang sama dengan iya. Jawaban L sesuai dengan yang diinginkan TW. Penguasaan maksim kuantitas terlihat pada data (4) seperti berikut ini.

Data 4

Konteks

L dan P sedang berada di kamar tidur. L mempersiapkan diri memakai pakaian bebas rapi. Kemudian, $\mathrm{P}$ melakukan pertuturan bersama L.

\begin{tabular}{|c|c|c|c|c|}
\hline \multicolumn{3}{|r|}{ Data } & & Interpretasi/Padanan \\
\hline P: & (a) & L mau kemana? & P: & L ingin kemana? \\
\hline L: & (b) & Telapi. & L: & Terapi. \\
\hline P: & (c) & Terapi sama siapa? & P: & Siapa yang nerapi? \\
\hline L: & (d) & Ma, udah, Ma. (sambil tersenyum) & L: & $\begin{array}{l}\text { Ma, aku sudah selesai memakai sepatu. (sambil } \\
\text { tersenyum) }\end{array}$ \\
\hline P: & (e) & $\begin{array}{l}\text { (Mengambil baju dan meletakkan di } \\
\text { almari) }\end{array}$ & P: & (Mengambil baju dan meletakkan di almari) \\
\hline L: & (f) & (Mengikuti P) & L: & (Mengikuti P) \\
\hline
\end{tabular}


Tuturan di atas diawali dengan pertanyaan $\mathrm{P}$ karena melihat $\mathrm{L}$ bersiap-siap dengan berpakaian rapi. Saat itu, L dan P berada di kamar tidur. Ketika L sudah berpakain rapi, P bertanya kepada $L$ seperti pada tuturan (a). L bertutur seperti pada (b) menjawab pertanyaan $P$. Kemudian, $\mathrm{P}$ bertanya kepada $\mathrm{L}$ seperti pada tuturan (d). L tidak menjawab pertanyaan $\mathrm{P}$ karena ia sedang memakai sepatu. Ketika ia selesai memakai sepatu, L bertutur kepada P seperti pada tuturan (d). P tidak merespons tuturan L karena pertanyaannya tidak dijawab seperti pada (e). Kemudian, L mengikuti P menuju ke almari yang berada di kamar seperti pada tuturan (f).

Data (4) di atas menunjukkan maksim kuantitas. Maksim kuantitas ditemukan L pada (b) yaitu telapi. Kata telapi memberikan informasi yang diperlukan P. L menunjukkan maksim kuantitas kepada P karena ia menjawab tidak secara berlebihan. Karena jawaban L kepada P tidak berlebihan, $\mathrm{P}$ menerima jawaban L dan bertanya kepadanya. Pertanyaan $\mathrm{P}$ pada (c) merupakan bentuk pengembangan pertanyaan ketika $\mathrm{L}$ berhasil menjawab pertanyaan $\mathrm{P}$ pada (a). Dengan demikian, data (4) menunjukkan prinsip kerja sama yang baik antara L dan P untuk menjalin komunikasi. Akan tetapi, tuturan L masih menunjukkan kekurangsempurnaan dalam pelafalan kata. Hal tersebut terdapat pada kata telapi seharusnya dilafalkan terapi. L masih belum mampu melafalkan bunyi [r] sehingga diganti menjadi [1]. Penguasaan maksim kuantitas terlihat pada data (5) seperti berikut ini.

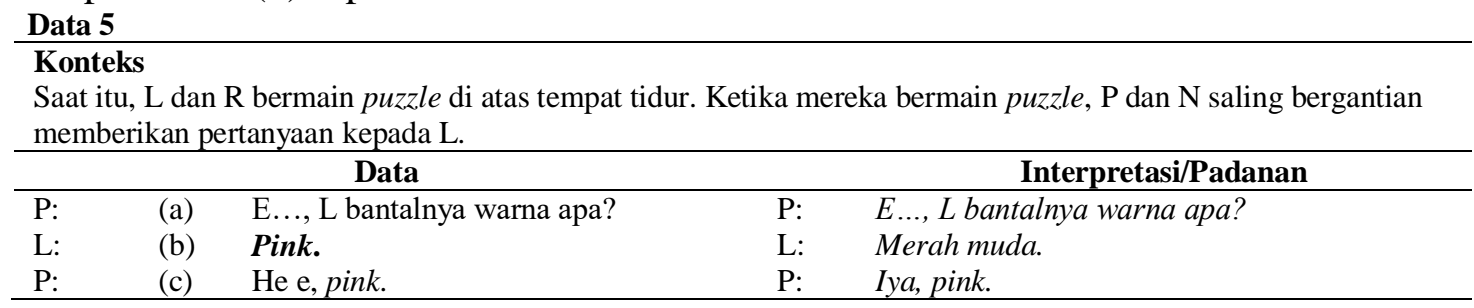

Pertuturan terjadi di kamar tidur. Saat itu, L dan R sedang bermain puzzle. Beberapa saat kemudian, $\mathrm{P}$ bertanya kepada L seperti pada tuturan (a). L menjawab pertanyaan $\mathrm{P}$ seperti pada tuturan (b). L menjawab pertanyaan dengan tepat karena sudah memahami warna bantal. P menerima jawaban L seperti pada tuturan (c).

Data (5) tuturan L mengandung maksim kuantitas. Maksim kuantitas ditunjukkan L pada (b) yaitu pink. Kata pink apabila diterjemahkan ke dalam bahasa Indonesia bermakna merah $m u d a$. Tuturan tersebut mengandung kontribusi yang sesuai diharapkan mitra tutur. $\mathrm{P}$ mengharapkan bahwa $\mathrm{L}$ dapat menjawab warna bantal yang ditunjuknya. L pada (b) yaitu pink menjawab dengan tepat. Hal tersebut disebabkan warna bantal yang ditunjuk P sudah dipahami L. Karena L masih sulit melafalkan kata merah muda, ia menggunakan kata berbahasa Inggris karena kata tersebut sering dituturkan famili L. Oleh sebab itu, L menuturkan kata pink. Penguasaan maksim kuantitas terlihat pada data (6) seperti berikut ini.

\begin{tabular}{|c|c|c|c|c|}
\hline \multicolumn{5}{|c|}{$\begin{array}{l}\text { Konteks } \\
\text { Setelah selesai mandi, L dan R bersiap-siap untuk memakai pakaian dibantu P. Saat P mempersiapkan pakaian, R } \\
\text { sedang membuka buku dan melambaikan tangan. Kemudian, L menggigil kedinginan dengan menggigit handuk. }\end{array}$} \\
\hline \multicolumn{3}{|c|}{ Data } & \multicolumn{2}{|c|}{ Interpretasi/Padanan } \\
\hline $\mathrm{R}:$ & (a) & $\begin{array}{l}\text { Halo, Mumun. (Melambaikan tangan } \\
\text { ke buku) }\end{array}$ & $\mathrm{R}:$ & $\begin{array}{l}\text { Halo, Mumun. (Melambaikan tangan ke } \\
\text { buku) }\end{array}$ \\
\hline P: & (b) & $\begin{array}{l}\text { Pakai seragam apa ini? Kak, hari ini } \\
\text { pakai seragam apa? (Mempersiapkan } \\
\text { beberapa pakaian dan menunjukkan } \\
\text { baju batik) }\end{array}$ & P: & $\begin{array}{l}\text { Hari ini pakai seragam apa, Kak L? } \\
\text { (Mempersiapkan beberapa pakaian dan } \\
\text { menunjukkan baju batik) }\end{array}$ \\
\hline L: & (c) & Batik. & L: & Batik. \\
\hline $\mathrm{R}:$ & (d) & Batik. (Suara pelan) & $\mathrm{R}:$ & Batik. (Suara pelan) \\
\hline P: & (e) & Batik, pinter. & P: & Batik, pintar L. \\
\hline
\end{tabular}


Pertuturan saat itu terjadi L dan R memakai pakaian di kamar. Ketika R memakai pakaian, $\mathrm{R}$ bertutur seperti pada tuturan (a) dengan menunjuk buku pelajarannya yang berada di atas kamar tidur. Sebelum P memakaikan seragam kepada L, P bertanya kepada L seperti pada tuturan (b). L menjawab pertanyaan P seperti pada tuturan (c). L menjawab dengan benar karena pertuturan terjadi pada hari Rabu. Kemudian, R mengulang jawaban L seperti pada tuturan (d). $\mathrm{P}$ memuji L karena ia menjawab pertanyaan $\mathrm{P}$ dengan benar seperti pada tuturan (e).

Data (6) menunjukkan maksim kuantitas. Maksim kuantitas ditunjukkan L pada (c) yaitu batik. La menjawab batik karena ia teringat bahwa pertuturan terjadi hari Rabu. Setiap Rabu dan Kamis, L diwajibkan memakai seragam batik. Kata batik memiliki informasi yang cukup atau memiliki kontribusi yang sesuai diharapkan P. Informasi yang cukup menunjukkan L dan $\mathrm{P}$ menjalin komunikasi dengan baik. Tuturan tersebut juga dirasa tidak berlebihan sehingga tuturan L pada (c) merupakan maksim kuantitas. Meskipun L dapat menggunakan maksim kuantitas, L masih memerlukan stimulus untuk menunjukkan maksim kuantitas. Apabila di dalam tuturan $\mathrm{P}$ tidak menunjukkan pakaian batik, L tidak akan menunjukkan maksim kuantitas.

\section{Penguasaan Maksim Kualitas}

Dalam bahasa Indonesia, maksim kualitas yaitu mewajibkan penutur mengatakan sesuatu sesuai dengan kenyataan. Pernyataan yang diungkapkan penutur harus disertai dengan buktibukti yang cukup. Pada penelitian ini, maksim kualitas diperoleh anak disabilitas intelektual dapat dilihat dari kebenaran tuturan anak menjawab pertanyaan dari mitra tutur. Penggunaan maksim kualitas anak disabilitas intelektual dapat dilihat dari kebenaran tuturan anak menjawab pertanyaan dari mitra tutur dijelaskan sebagai berikut.

\section{Data 7}

Konteks

Pertuturan P dan L terjadi di kamar tidur. P duduk di atas tempat tidur, sedangkan L menggambar sesuatu di buku. Kemudian, P teringat bahwa saat itu hari Senin dan melakukan pertuturan dengan L.

\begin{tabular}{lllll}
\hline & \multicolumn{1}{c}{ Data } & & \multicolumn{1}{c}{ Interpretasi } \\
\hline P: & (a) & L, tadi ada olahraga? & P: & L, tadi apakah ada olahraga? \\
L: & (b) & He e. & L: & Iya. \\
P: & (c) & Heh. & P: & Apa? \\
L: & (d) & He e. & L: & Iya. \\
P: & (e) & Siapa se guru olahragamu? & P: & Siapa guru olahragamu? \\
L: & (f) & Aripin. & L: & Pak Arifin. \\
P: & (g) & Pak Aripin & P: & Pak Arifin. \\
\hline
\end{tabular}

Pertuturan di atas terjadi hari Senin. Pada hari Senin, L ada pelajaran olahraga di sekolah. Beberapa saat kemudian, P pada tuturan (a) bertanya kepada L. Kemudian, L menjawab pertanyaan P seperti pada (b). P terlihat tidak mendengar dengan jelas tuturan L dan bertutur pada (c). Tuturan L pada (d) mempertegas jawabannya kepada P. Tuturan P pada (e) sebenarnya $P$ sudah mengetahui nama guru olahraga L. Hanya saja, $\mathrm{P}$ menguji kemampuan daya ingat $\mathrm{L}$ sehingga $\mathrm{P}$ bertanya kepada L seperti pada tuturan (e). L menjawab pertanyaan $\mathrm{P}$ seperti pada (f).

Data (7) di atas menunjukkan tuturan L terdapat maksim kualitas. Maksim kualitas ditunjukkan L pada (b) dan (f) yaitu he...e dan Aripin. Apabila diinterpretasikan, kata he $e$ memiliki persamaan makna dengan kata iya. Kata iya bermakna menyetujui atau membenarkan sebuah peristiwa yang terjadi. Maksim kualitas yang ditunjukkan L berupa fakta karena peristiwa yang sudah terjadi. Penutur dan mitra tutur terikat akan kebenaran suatu peristiwa untuk menunjukkan maksim kualitas. Pada data (7), L pada (b) yaitu he e membuktikan bahwa di sekolahnya terdapat pelajaran olahraga. Hal tersebut ditunjukkan pada waktu pertuturan. Waktu pertuturan menunjukkan hari Senin. Setiap hari Senin, L ada pelajaran olahraga. Informasi yang dituturkan L sudah tepat. Oleh sebab itu, L pada (b) merupakan maksim 
kualitas. L pada (f) juga menunjukkan maksim kualitas karena L mengatakan sesuatu sesuai dengan kenyataan. Tuturan L pada (f) terdapat defisit kata, yakni Aripin. Seharusnya, kata Arifin dituturkan Pak Arifin karena beliau adalah guru olahraganya. L sering menghilangkan kata yang berada pada awal kata karena berbicara terlalu cepat. Hal tersebut juga terjadi pada pelafalan kata. Bunyi [p] pada kata Aripin seharusnya dilafalkan Arifin. Seharusnya, L melafalkan [f] bukan [p]. Hal tersebut terjadi karena L berbicara terlalu cepat. Penguasaan maksim kualitas terlihat pada data (8) berikut ini.

\begin{tabular}{|c|c|c|c|c|}
\hline \multicolumn{5}{|c|}{ Konteks } \\
\hline \multicolumn{4}{|c|}{ Data } & $\begin{array}{c}\text { Interpretasi } \\
\text { (mengoeser alat terani berung gambar }\end{array}$ \\
\hline L: & (a) & $\begin{array}{l}\text { (menggeser alat terapi berupa gambar } \\
\text { hewan) }\end{array}$ & L: & $\begin{array}{l}\text { (menggeser alat terapi berupa gambar } \\
\text { hewan) }\end{array}$ \\
\hline TO: & (b) & $\begin{array}{l}\text { Sebentar. Kamu dari mana? L dari mana? } \\
\text { Dari mana? }\end{array}$ & TO: & $\begin{array}{l}\text { Sebentar. Kamu dari mana? L dari } \\
\text { mana? }\end{array}$ \\
\hline L: & (c) & Tekola. (berbicara pelan) & $\mathrm{L}:$ & Sekolah. (berbicara pelan) \\
\hline TO: & (d) & $\begin{array}{l}\text { Sekolah. L sekolah di mana? Di mana? Di } \\
\text { mana? E..lihat-lihat, sekolah di mana? }\end{array}$ & TO: & $\begin{array}{l}\text { Sekolah. L sekolah di mana? Lihat } \\
\text { saya, sekolah di mana? }\end{array}$ \\
\hline L: & (e) & $\begin{array}{l}\text { Kelas dua. (Menunjukan jari angka dua } \\
\text { kemudian angka tiga) }\end{array}$ & L: & $\begin{array}{l}\text { Kelas dua. (Menunjukan jari angka dua } \\
\text { kemudian angka tiga) }\end{array}$ \\
\hline
\end{tabular}

Pertuturan di atas terjadi ketika L menggeser alat terapi seperti pada tindakan (a). Ketika L menggeser alat terapi, TO memerintah L seperti pada tuturan (b). Kemudian, TO bertanya kepada L sebelum melakukan terapi. L menjawab pertanyaan TO seperti pada tuturan (c). TO menerima jawaban L dan bertanya kepadanya seperti pada tuturan (d). L menjawab pertanyaan TO seperti pada tuturan (e) meskipun jawaban yang diberikan kurang tepat.

Data (8) di atas terdapat maksim kualitas. Maksim kualitas ditunjukkan L pada (c) yaitu tekola (sekolah). Kata tekola dituturkan L untuk memberikan kontribusi berupa jawaban kepada TO. Sebelum L berangkat ke tempat terapi, ia bersekolah terlebih dahulu. Oleh sebab itu, tuturan L pada (c) mengandung kebenaran. Hal itu juga ditunjukkan tuturan TO pada (d) yaitu Sekolah...dengan cara menerima jawaban L. Tuturan L pada (c) yakni tekola masih menunjukkan kekurangsempurnaan dalam melafalkan kata. Seharusnya, kata tekola dilafalkan sekolah. L belum mampu melafalkan bunyi [s] pada awal kata sehingga diganti menjadi [t]. Penguasaan maksim kualitas terlihat pada data (9) berikut ini.

\begin{tabular}{|c|c|c|c|c|}
\hline & \multicolumn{4}{|c|}{ Konteks } \\
\hline \multicolumn{5}{|c|}{$\begin{array}{l}\text { Pertuturan antara } \mathrm{P} \text { dan } \mathrm{L} \text { terjadi di kamar tidur. } \mathrm{L} \text { sedang belajar, sedangkan } \mathrm{R} \text { bermain puzzle. Ketika } \mathrm{L} \text { sedang } \\
\text { belajar, } \mathrm{P} \text { bertanya kepada } \mathrm{L} \text { tentang teman sekelasnya yang tidak masuk hari itu. }\end{array}$} \\
\hline & & Data & & Interpretasi \\
\hline P: & (a) & Siapa yang nggak masuk? & P: & Siapa yang tidak masuk? \\
\hline L: & (b) & Tino ndak matuk. & $\mathrm{L}:$ & Sinyo tidak masuk. \\
\hline P: & (c) & $\begin{array}{l}\text { Sinyo? Sinyo ndak masuk. Kenapa } \\
\text { nggak masuk? }\end{array}$ & P: & Sinyo? Mengapa Sinyo tidak masuk? \\
\hline L: & (d) & Takit. & L: & Sakit. \\
\hline P: & (e) & Sakit. & P: & Sakit. \\
\hline
\end{tabular}

Pertuturan di atas diawali P bertanya seperti pada tuturan (a) mencari informasi kepada L tentang teman sekelasnya yang tidak masuk pada hari itu. Ketika P bertanya kepada L, R sedang bermain puzzle, sedangkan $\mathrm{N}$ terlihat duduk di lantai melihat $\mathrm{L}$ menulis. Beberapa saat kemudian, L bertutur seperti pada (b) menjawab pertanyaan P. Tuturan P pada (c) terlihat meragukan jawaban L dan bertanya kepada L alasan Sinyo tidak masuk sekolah. L memberikan jawaban kepada P seperti pada tuturan (d). P mengulang jawaban L seperti pada tuturan (e).

Data (9) di atas menunjukkan tuturan V terdapat maksim kualitas. Maksim kualitas yang ditunjukkan L mengandung fakta atau sesuatu yang benar-benar terjadi. Maksim kualitas di atas ditunjukkan L pada (b) dan (e) yaitu Tino ndak matuk dan Takit. L memberikan kontribusi 
sebenarnya kepada $\mathrm{P}$ sesuai dengan peristiwa pertuturan terjadi. Peristiwa tutur yang ditunjukkan L adalah Tino (Sinyo) teman sekelas L tidak masuk sekolah pada hari tersebut sebelum pertuturan terjadi. Untuk menyakinkan $\mathrm{P}$ bahwa informasi yang disampaikan $\mathrm{L}$ benar, L pada (d) yakni takit (sakit) memberikan alasan berupa alasan Tino tidak masuk sekolah. L pada (d) memperkuat maksim kualitas karena pertuturan disertai dengan bukti. Kualitas seseorang bertutur dapat terlihat dari kebenaran pada isi pertuturan. Apabila pertuturan mengandung ketidakbenaran, tidak akan terjadi kerja sama dengan baik. L pada (d) terdapat kekurangsempurnaan pelafalan kata. Seharusnya, kata Tino dilafalkan Sinyo dan kata matuk dilafalkan masuk. L belum mampu melafalkan bunyi [s] pada awal dan tengah kata sehingga bunyi [s] diganti dengan [t]. Selain itu, bunyi [ny] hanya dilafalkan [n] oleh L karena ia berbicara terlalu cepat sehingga pelafalan [ny] kurang jelas. Selain itu, bunyi [s] pada kata sakit dilafalkan takit karena belum mampu melafalkan bunyi [s] pada awal kata. Penguasaan maksim kualitas terlihat pada data (10) berikut ini.

\begin{tabular}{|c|c|c|c|c|}
\hline \multicolumn{5}{|c|}{$\begin{array}{l}\text { Konteks } \\
\text { L berbaring tidur di kamarnya sambil memegang handphone. Ketika L berbaring tidur, P melakukan pertuturan } \\
\text { dengan L. }\end{array}$} \\
\hline \multicolumn{3}{|c|}{ Data } & \multicolumn{2}{|c|}{ Interpretasi } \\
\hline L: & (a) & $\begin{array}{l}\text { Lama Ma, Ma. (menoleh ke P dan } \\
\text { menunjukkan handphone-nya kepada P) } \\
\text { Ma, Ma lama Ma? }\end{array}$ & L: & $\begin{array}{l}\text { Lama Ma, Ma. (menoleh ke P dan } \\
\text { menunjukkan handphone-nya kepada P) } \\
\text { Ma, lama loading-nya? }\end{array}$ \\
\hline P: & (b) & Hem. & P: & Hem. \\
\hline $\mathrm{L}:$ & (c) & Kenapa? & $\mathrm{L}:$ & Mengapa lama? \\
\hline P: & (d) & Ditunggu itu loding itu. & P: & Ditunggu dulu masih loading. \\
\hline $\mathrm{L}:$ & (e) & Loding? & $\mathrm{L}:$ & Loading? \\
\hline P: & (f) & Main apa itu kamu? & P: & Main apa itu kamu? \\
\hline L: & (g) & Mobil-mobilan. & $\mathrm{L}:$ & Mobil balap. \\
\hline P: & (f) & Oh, Main mobil balap. & P: & Oh, Main mobil balap. \\
\hline
\end{tabular}

Pertuturan terjadi ketika L ingin bermain game pada handphone P. Karena L lelah menunggu permainan dimulai, L bertutur kepada $P$ seperti pada (a). Respons yang ditunjukkan $P$ seperti pada tuturan (b) menjawab pertanyaan L. Karena L tidak mendapatkan jawaban yang tepat dari P, L bertanya kepada P seperti pada tuturan (c). Kemudian, P bertutur seperti pada (d) menjelaskan kepada L. Akan tetapi, L kurang memahami maksud kata loading sehingga ia bertanya kembali kepada $\mathrm{P}$ seperti pada tuturan (e). P tidak menjawab pertanyaan L. Kemudian, $\mathrm{P}$ bertanya kepada L seperti pada tuturan (g) karena ia penasaran dengan game yang dimainkan L. Dengan jelas, L menjawab pertanyaan $\mathrm{P}$ seperti pada tuturan $(\mathrm{g})$. P mengulang kembali jawaban L seperti pada tuturan (f) karena jawaban yang diberikan L serupa dengan mobil.

Data (10) tampak menunjukkan maksim kualitas. Maksim kualitas ditunjukkan tuturan L pada (g) yaitu mobil-mobilan. Kata mobil-mobilan bermakna sebuah permainan yang berada di handphone. Tuturan tersebut memberikan informasi yang sebenar-benarnya kepada $\mathrm{P}$ bahwa $\mathrm{L}$ sedang bermain mobil meskipun jawaban yang paling tepat adalah mobil balap. Seperti yang telah dijelaskan pada analisis sebelumnya, L masih belum mampu melafalkan beberapa huruf dengan tepat dan kosakata yang dikuasai juga terbatas. Oleh sebab itu, kata mobil-mobilan merupakan informasi yang mengandung kebenaran. L pada $(\mathrm{g})$ termasuk maksim kualitas. Meskipun sebenarnya permainan dalam game tersebut mobil balap, L pada (g) yaitu mobilmobilan sudah memberikan informasi yang benar. Tuturan $\mathrm{L}$ pada $(\mathrm{g})$ menunjukkan bahwa $\mathrm{L}$ mampu menggunakan reduplikasi kata yang bersufiks dengan baik. Penguasaan maksim kualitas terlihat pada data (11) berikut ini. 
Data 11

Konteks

Pertuturan terjadi ketika L sedang bermain game balap mobil. Sambil menunggu game dimulai, P melakukan pertuturan dengan L.

\begin{tabular}{lllll}
\hline \multicolumn{1}{c}{ Data } & \multicolumn{1}{c}{ Interpretasi } \\
\hline L: & (a) & Pink, a, b, c, d, e, f, g, h, i, j, k, m, l, n, o, & L: & Pink, $a, b, c, d, e, f, g, h, i, j, k, m, l, n, o, p$, \\
& & p, q r, s, t, u, w, w, x, y, y, z. (bernyanyi) & & $q r, s, t, u, w, w, x, y, y, z .($ bernyanyi) \\
P: & (b) & Pinter. Kamu tadi ndak les, kenapa? & P: & Pintar. Kamu tadi tidak les, kenapa? \\
L: & (c) & Bubuk. & L: & Aku tertidur. \\
P: & (d) & Bubuk, udah janjian apa belum? & P: & Tidur, sudah janjian les apa belum? \\
L: & (e) & Udah. & L: & Sudah. \\
\hline
\end{tabular}

Pertuturan berawal saat L bernyanyi mengurutkan huruf alfabetis seperti pada tuturan (a). L bernyanyi sambil bermain game mobil balap di handphone-nya. Ketika L selesai bernyanyi, P memuji L dan bertanya kepadanya seperti pada tuturan (b). L menjawab pertanyaan P seperti pada (c). P mengulang jawaban L. Kemudian, P bertanya kembali kepada L seperti pada tuturan (d). P beranggapan bahwa $\mathrm{L}$ tertidur karena ia belum membuat perjanjian dengan guru les privat. Respons yang ditunjukkan L menjawab pertanyaan $\mathrm{P}$ seperti pada tuturan (e).

Data (11) menunjukkan tuturan L mengandung maksim kualitas. Maksim kualitas ditunjukkan L pada (c) dan (e) yaitu bubuk dan udah. Kata bubuk apabila diterjemahkan ke dalam bahasa Indonesia bermakna sama dengan tidur. L menuturkan kata bubuk karena les privat dilakukan setelah pulang sekolah pukul 13.00 WIB sehingga ia merasa lelah dan tertidur. Kata bubuk mengandung maksim kualitas karena L memberikan informasi sebenarnya kepada P. L pada (e) yaitu udah juga mengandung maksim kualitas karena menginformasikan sesuai dengan fakta. Dengan demikian, L pada (b) dan (e) merupakan maksim kualitas. Tuturan L pada kata udah merupakan kekurangsempurnaan pelafalan. L belum mampu melafalkan bunyi [s] pada awal kata sehingga bunyi tersebut tidak dilafalkan

Penelitian tentang anak disabilitas intelektual atau tunagrahita ditulis oleh Anggraeni (2014). Dalam penelitian tersebut, dikaji tentang anak tunagrahita terkait realisasi dan variasi pelafalan. Hasil temuan penelitian ini dikategorikan menjadi anak tunagrahita ringan, sedang, dan berat. Anak tunagrahita ringan sudah menunjukkan pelafalan bunyi hampir sempurna dan dapat dimengerti. Akan tetapi, terdapat pelafalan bunyi yang cadel seperti [m] berhadapan dengan bunyi [ə]. Anak tunagrahita sedang pelafalannya hampir sempurna, namun terdapat pelafalan yang masih tidak dapat dipahami seperti bunyi bunyi [n] sering tidak dilafalkan di tengah kata. Anak tunagrahita berat sering tidak melafalkan bunyi atau mengubah bunyi sehingga menjadi makna yang tabu. Penelitian tersebut memunyai persamaan dan perbedaan dengan penelitian ini. Persamaan penelitian adalah ada pelafalan bunyi yang kurang sempurna, sedangkan perbedaan penelitian terdapat pada bunyi yang belum mampu dilafalkan. Dalam penelitian tersebut, ditemukan bahwa ada pelafalan S yang kurang sempurna pada bunyi [m] berhadapan dengan bunyi [ə], sedangkan S dalam penelitian ini sudah mampu melafalkan bunyi tersebut. S penelitian ini belum mampu melafalkan bunyi [r] dan [s] pada awal dan tengah kata. Hal tersebut menunjukkan bahwa tiap anak disabilitas intelektual memiliki kemampuan melafalkan bunyi berbeda-beda.

Artikel yang meneliti anak tunagrahita pernah ditulis oleh Rosmiati (2019). Hasil analisis data menjelaskan (1) pemerolehan fonologis, yaitu pelafalan bunyi [r] dan [z] masih sulit; (2) pemerolehan morfologis, yaitu pembentukan kata, seperti morf, morfem, dan kata sudah tampak pada tuturan; (3) pemerolehan sintaksis, yaitu pola kalimat sederhana S-P-O, S-P-K, KP-S, dan terdapat kalimat perintah. Penelitian tersebut memiliki persamaan dengan penelitian ini, yaitu L belum mampu melafalkan bunyi [r] dan [z]. Selain persamaan, hasil analisis data penelitian ini memunyai perbedaan yaitu tuturan L masih didominasi dengan penggunaan kata yang minim, pemerolehan morfologis belum sempurna yaitu L belum mampu melafalkan afiks. Selain itu, V juga masih kesulitan untuk merangkai kalimat sederhana. 


\section{PENUTUP}

Berdasarkan hasil analisis data di atas, dapat disimpulkan bahwa $\mathrm{L}$ sudah dapat menguasai maksim kuantitas dan maksim kualitas. Akan tetapi, temuan data pada tuturan L masih menunjukkan satu kata, defisit penggunaan afiks, kekurangsempurnaan beberapa pelafalan bunyi, seperti $[\mathrm{r}]$ dan [s] pada awal kata dan tengah kata.

Penelitian ini menggunakan kajian psikolinguistik dan pragmatik, khususnya pada prinsip kerja sama yaitu maksim kuantitas dan maksim kualitas. Dengan demikian, peneliti lain dapat menambah maksim yang lain atau menindaklanjuti dengan kajian seperti sintaksis, morfologi, semantik, dsb. Penelitian ini dapat dijadikan sarana terapi untuk anak disabilitas intelektual ringan yang mengalami keterlambatan bicara dalam bertutur dan referensi saat berkomunikasi dengan anak tersebut.

\section{DAFTAR PUSTAKA}

Abdul, R. D. (2006). Analisis Wacana Sebuah Kajian Bahasa dalam Pemakaian. Malang: Bayu Media Publishing. Anggraeni, D. Y. (2014). Tuturan pada Anak Penyandang Tunagrahita Taraf Ringan, Sedang, dan Berat (Kajian Fonologi). Bahtera Sastra: Antologi Bahasa dan Sastra Indonesia, 1(2), 1-5.

Djajasudarma, F. (2012). Wacana dan Pragmatik. Bandung: Refika Aditama.

Efendi, M. (2006). Pengantar Psikopedagogik Anak Berkelainan. Jakarta: Bumi Aksara.

Grice, H. P. (1975). Logic and Conversation. New York: Oxford University Press.

Kasih, R. C. (2019). Modelling Untuk Meningkatkan Interaksi Sosial pada Anak dengan Intellectual Disability. Jurnal Diversita, 5(1), 51-57. https://doi.org/10.31289/diversita.v5i1.2372

Leech, G. (1993). Prinsip-Prinsip Pragmatik. Jakarta: Universitas Indonesia.

Leung, A. K. C., \& Kao, C. P. (1999). Evaluation and Management of The Child with Speech Delay. In American Family Physician, 59 (11):3121-3128.

McLaughlin, M. R. (2011). Speech and Language Delay in Children. American Family Physician, 83(10), 11831188.

Mustikawati, N., Anggorowati, D., \& Mugianingrum, O. E. (2015). Kemampuan Sosialisasi Anak Retardasi Mental. Jurnal Ilmiah Kesehatan, 8(2).

Nilawati, E., \& Suryana, D. (2012). Gangguan Terlambat Bicara (Speech Delay) dan Pengaruhnya terhadap Social Skill Anak Usia Dini. Jurnal. Padang: Perpustakaan Universitas Negeri Padang.

Pandudinata, R., Sumarlam, S., \& Saddhono, K. (2018). Pemerolehan Bahasa Siswa Tunagrahita Kelas VI SD. RETORIKA. Jurnal Bahasa, Sastra, dan Pengajarannya, 11(1), 48-56. https://doi.org/10.26858/retorika.v11i1.4988

Papalia, D. E., Gross, D. L., \& Feldman, R. D. (2003). Child Development: A Topical Approach. McGraw-Hill Humanities, Social Sciences \& World Languages.

Rahardi, R. K. (2005). Pragmatik: Kesantunan Imperatif Bahasa Indonesia. Jakarta: Erlangga.

Rahardi, R. K. (2009). Sosiopragmaik. Jakarta: Erlangga.

Rohmadi, M. (2011). Analisis Wacana Pragmatik. Surakarta: Yuma Pustaka.

Schalock, R. L., Borthwick-Duffy, S. A., Bradley, V. J., Buntinx, W. H. E., Coulter, D. L., Craig, E. M., Gomez, S. C., Lachapelle, Y., Luckasson, R., \& Reeve, A. (2010). Intellectual Disability: Definition, Classification, and Systems of Supports. ERIC.

Shetty, P. (2012). Speech and Language Delay in Children: A Review and The Role of Pediatric Dentist. In Journal of Indian Society of Pedodontics and Preventive Dentistry. https://doi.org/10.4103/0970$\underline{4388.99979}$

Somantri, S. (2007). Anak Tunagrahita. Yogyakarta: Kanwa Publisher.

Steinberg, D. D., Nagata, H., \& Aline, D. P. (2001). Psycholinguistics: Language, Mind, and World. London: Longman.

Sularyo, T. S., \& Kadim, M. (2016). Retardasi Mental. Sari Pediatri, 2(3), 170-177. https://doi.org/10.14238/sp2.3.2000.170-7

Tiel, J. M. V. (2016). Anakku Gifted Terlambat Bicara. Jakarta: Prenada Media.

Wardani, I., Hernawati, T., \& Somad, P. (2008). Pengantar Pendidikan Luar Biasa. Jakarta: Universitas Terbuka. Wijana, I. D. P., \& Rohmadi, M. (2010). Analisis Wacana Pragmatik: Kajian Teori dan Analisis. Yuma Pustaka. 